\title{
マニピュレータの自律的障害物回避動作を 高速化するためのセンサ統合システム
}

\author{
正員山田陽 滋 (豊田工大) \\ 正員土田縫 夫 (豊田工大)
}

\section{A Sensor Integration System for High-Speed Autonomous Collision Avoidance Movements of a Manipulator \\ Yoji Yamada, Member, Nuio Tsuchida, Member(Toyota Technological Institute)}

This paper deals with a system with originally developed visual and proximity-tactile sensors mounted on a 2-link manipulator. A sensor integration system for autonomous collision avoidance movements in real time is proposed firstly and the hierarchical structure of the system is described. The strategy to control the manipulator is nextly proposed, which includes how to plan a global path by using visual sensor data and a local path correction procedure with proximity-tactile sensor signals directly given to the servo controller. Finally, an experimental result is shown in which the manipulator is controlled according to the strategy. The time spent for the system to do with a stair-shaped obstacle was about $22 \mathrm{~s}$ in which only $3.3 \mathrm{~s}$ was required for calculating a global path, which shows the effectiveness of the developed sensor integration system.

キーワード: 障害物回避, センサ統合, 視覚センサ, 近接覚一触賞センサ, 経路計画, 経路変更

\section{1. 序}

\section{論}

本研究は，2リンクアームによる自律的な障害物回 避動作に関するものである。垂直多関節形マニピュレ 一タシステムに独自に開発した視覚拉よび近接覚一触 賞センサを付加し，それらのセンサから得られたデー 夕を統合的に利用することにより，自律動作の応答の 高速化を図ることを目的とした。

複数のセンサを用いてロボットの自律的な動作の信 頼性を向上させる試みは，特に移動口ボットの分野て 多くなされてきだ(1)(2)。最近では，TVカメラから得 られる視覚情報と超音波センサから得られる近接覚情 報を統合化して確実な移動経路を決定するシステムも 報告されている(3)。しかしながら，これらの技術をそ のままマニピュレータに適用すると幾つかの問題が 生じる。まず，移動ロボットの場合には，木に水平な 二次元平面内の物体の移動をモデルとして与えて経路 探索を行う場合が多いのに対して，マニピュレータの
場合には三次元的な経路を求める必要があり、システ 厶の応答時間内に占める探索時間の割合が大きくな る。また、マニピュレータでは，経路を局所的に変更 するにも高速性が要求される。従って，システムを高 速化するためには，動作経路の計画時間および実際の 動作時間の両方の短縮化を図らなければならない。

本研究では，第一段階として，マニピュレータが自 律的に作業環境をとらえて動作経路を計画するため に，検出範囲の広い視賞センサのデータを用いて，大 域的観点に立った経路の探索を行う。さて, 動作経路 の自動計画に関するこれまでの研究の中では,（i ) ポ テンシャル法(4)，(ii)笁間セル法(5)，(iii) 準空間法(6) をそれぞれ利用したものが大きな成果を取めている。 これらの中で( i)抢よぴ(ii)のアプローチは, 自動計 画の前処理にあたる空間の記述に多くのプログラミン グと処理時間を要する。この点で(iii)の場合には, 幾 何学的な関数表現を活用でき, 処理時間を短縮するこ とができるという点で実時間処理に適している。この 
手法では, パラメータを固定した各準空間内でマニピ ュレータが障害物を回避することのできる候補姿勢を 算出しておき，パラメータを変化させたときに最適な 姿勢変化を与えるジョイント角の系列を探索するとい ラアルゴリズムが用いられる。従って, パラメータの 変化が小刻みでその準空間の数 $n$ が大きいと, 経路 探索に要する計算量も多くなり, 応答時間の遅れの原 因になる。これを避けるために, 経路計画の段階で検 出デー夕をより離散的に削減し， $n$ を減らすことによ って，探索作業の負荷を軽隇するアプローチが考えら れる。しかし, 検出データが減ると, 回避経路を決定 するのに情報量が不十分な局面が現れる。

そこで，この信頼性の低下を補償する目的で，第二 段階として, 検出領域は狭いが高速に障害物との干涉 を検出できる近接覚-触覚センサ $(\langle 2 \cdot 1\rangle$ 節参照) を用 い，その情報に応じて経路の局所的な变更を実時間的 に行う制御手法を考えた(7)。

以下の章では，まず，独自に開発した視覚および近 接覚一触賞センサをマニピュレータに実装し,これら によって得られる情報を統合的に利用できるセンサ統 合システムについて, その階層的なフィードバック構 造を説明する。次に, 視賞情報を用いて生成した経路 に沿ってマニピュレータを動作させながら,アクチュ エータに直接フィードバックされる近接覚および触覚 信号を利用して障害物を局所的に回避する制御戦略を 提案する。最後に, この戦略に従って実際にマニピュ レータを制御した結果を表し, システムの評価を 行う。

\section{2. センサ統合システムの構成}

マニピュレータ（三菱電機製 MOVEMASTER EX）に視覚わよび近接賞一触覚センサを装着して, そ の情報を統合的に利用することのできるセンサ統合シ ステムを構成した。マニピュレータは 5 自由度を有す る垂直多関節形で, その 2 リンク部分 (3 自由度) が 用いられる。

\section{〈2・1〉 視覚および近接覚一触覚センサの実装}

図1にシステムの構成図を, また図 2 にその外観写 真を示す。本シズテムで用いられる視覚センサ $S_{V}$ は, 障害物表面の三次元的な位置座標を求めることが できるもので，その検出デー夕はセンサ座標系 $\boldsymbol{O}_{v}$ に おいて $(\theta, r, z)$ の円柱座標で出力される(8)。ここ で， $\theta$ はマニピュレー夕の第一ジョイント $\theta_{1}$ 軸（図 9 参照) に一致している。そのため, $\boldsymbol{O}_{v}$ からマニピ ユレータの動作を記述する基準（円柱）座標系 $\boldsymbol{O}$ へ の座標変換は簡単になり, 計算処理時間が短縮され

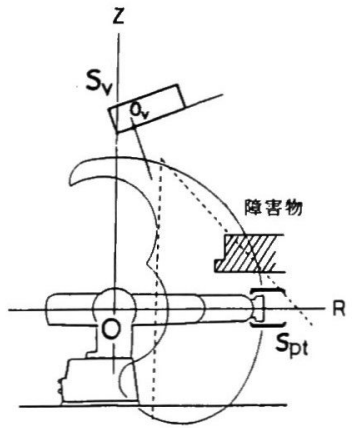

図 1 視覚および近接覚一触覚センサの装着 Fig. 1. Equipment of visual and proximitytactile sensors.

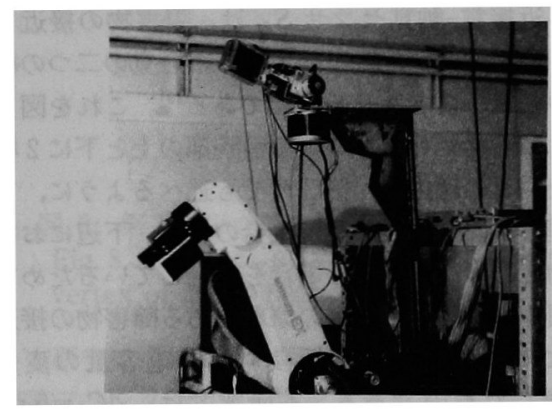

図 2 センサ統合システムの外観写真 Fig. 2. Photo of the sensor integration system.

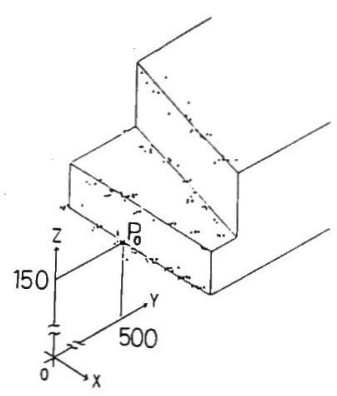

図 3 三次元位置検出結果

Fig. 3. Result of 3D position detection.

る。図 3 はマニピュレータの直交作業座標系にお いて,

$$
P_{0}(x, y, z)=(0,500,150)
$$

の位置に置かれた階段状の障害物の検出結果である。 この場合の最大誤差は, $R$ 方向で $17.1 \mathrm{~mm}, Z$ 方向 で $14.7 \mathrm{~mm}$ であった。 


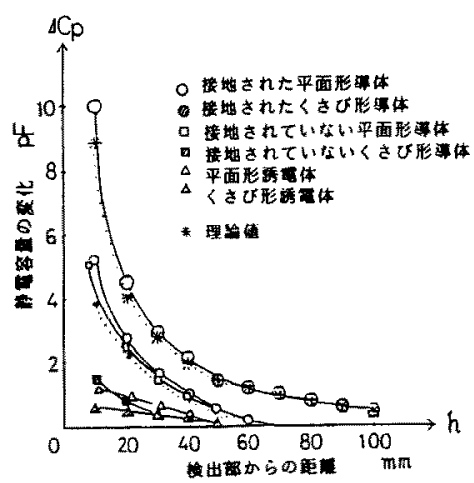

図 4 近接賞部の検出特性

Fig. 4. Characteristics of proximity sensing.

一方, 近接賞一触覚センサ $\boldsymbol{S}_{p t}$ は, 障害物の接近を 検出する近接賞と，接触を検出する接触賞の二つの機 能を一つの素子にもたせるものである(9)。これを図 1 示す上うに, マニピュレータの前腕部の上と下に 2 枚 装着した。この理由は，第了章ても述べるように，ア 一ムを垂亩平面上に投影した場合の上辺，下辺におい て障害物との干涉が生じる場合を想定しているためで ある。図 4 は $S_{p t}$ の近接覚の原理である障害物の接近 距離 $h$ に対するセンサ電極の対地静電容量の変化 $\Delta C_{p}$ を表したものである。本研究では， $\Delta C_{p}=5 \mathrm{pF}$ 程度で障害物の接近を検出し始めるように設定されて いる。ただし，同図に見られるように，平面あるいは かどがそれぞれ接近する場合で，これを検出し始める 距離が $10 \mathrm{~mm}$ 程度の差を有する。

〈2・2〉 システムのブロック構成＼cjkstart図 5 は提案す るセンサ統合システムに抬けるセンサ信号の流れを表 している。本システムは，センサ信号を経路プラナゃ コントローラまで階層的にフィードバックする構成と した。

まず， $S_{V}$ のデータはシリアルインタフェースを介 して, マニピュレータの動作経路を計画するための経 路プラナに入力される。一方， $S_{p t}$ から得られる障害 物の干涉検出データのうち，A/D変換された 8 ビッ トの近接賞データは，㱟サーボ CPUを介して第三ジ ヨイントのサーボコントローラへ直接フィードパック

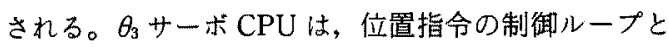
は非同期で動作し，そのサンプリング時間は $5 \mathrm{~ms} て$ ある。

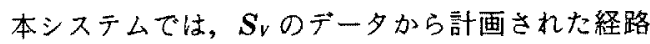
に更に近接覚データが加算される形でセンサデータの 統合が行われる。ただし、ゴール地点近傍に障害物が ある場合, 近接賞が働き続けると, マニピェレータが

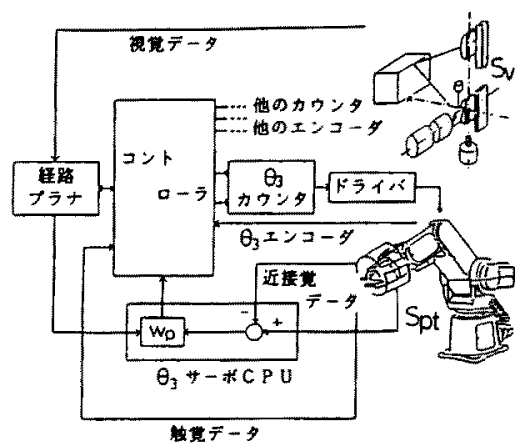

図 5 システムに抬けるセンサ信号の流れ

Fig. 5. Signals' flow in the system.

ゴール地点に到達できない。そこでこの地点におい て，経路プラナからの指令によって加味される近接賞 デー夕の重みを 0 とすることができるように $w_{p}$ が設 けられている。

他方の接触覚の $\mathrm{ON}$ ・OFF デー夕は, 応答が $20 \mathrm{~ms}$ 程度で, コントローラCPUへの割込み信号として入 力され, マニピュレータの非常停止を司る。

\section{3. 動作経路の計画と变更}

マニピュレータの作業領域内において, 存在する障 害物より上側は，すべて自由空間，すなわちマニピュ レータが自由に動作できる架間であるとする(sky. ward property $\left.{ }^{(10)}\right) 。 こ の$ 仮定が成立する局面は，ピ ックアンドプレースなどマニピュレータが対象とする 作業に多〈存在する。本論文では, この仮定のもと で，オペレータによって与えられたスタートSから ゴール $G$ まて，マニピュレータに自律的に障害物を 回避しながら移動させる方策として以下に示す制御手 法を提案する。すなわち, 第一ステップとして, 経路 プラナでは, 視覚センサから得られた検出デー夕を用 いて大域的な動作経路を計画する。そして第二ステッ プとして，実際のマニピュレータに計画された経路に 沿って動作をさせるが, その間, 近接覚一触覚センサ によって障害物との干渉をチェックし続ける。もし， 近接賞センサが働いたら, 駆動ジョイントへの直接つ イードバック指令により，局所的な経路変更動作をす る。更にもし，触覚センサが働いたら，マニピュレー 夕の動作を停止した後, 経路プラナによって局所的に 経路の計面を立て直す。

〈3.1〉大域的な経路計画 第 2 章で述へたよう に, マニピュレータの三次元的な動作空間を，その第 一ジョイント角 $\theta_{1}=\theta_{1 x}(i=S, S+1,2, \cdots, G-1, G)$ で決定される淮空間であるところの $\theta_{1}$ 平面の集合と 


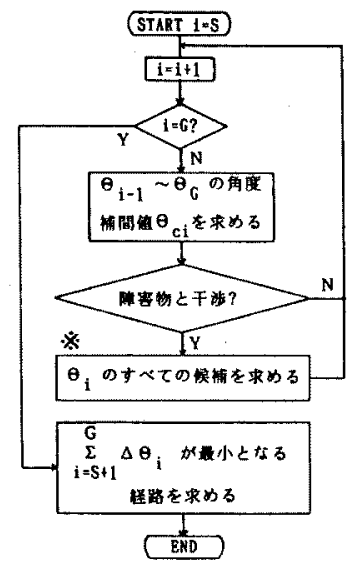

図 6 大域的経路計画のための流れ図

Fig. 6. Flowchart for global path planning.

して記述する。つ交り, マニピュレータの動作を決定 するジョイント角のうち $\Theta=\left(\theta_{2}, \theta_{3}\right)$ と, 視覚センサ による検出点をマニピュレータの円柱座標系に変換し たデータとを離散的な $\theta_{1}$ の值をパラメータとしてメ モリーに格納する。このとき，データの中からまず視 覚センサにとって死角となる領域を除外し, 更に適当 な点を選び出して連結することによって, 障害物を包 含する凸多角形 $\boldsymbol{B}_{\boldsymbol{i}}$ を構成する。この前処理は, 情報 量を圧縮し干涉チェックに要する計算量を削減するの に寄与する。

本論文では，動作経路を決定するにあたり，Sから $G$ までの移動時間が最小となるように，図 6 に示す 流れ図に従って $\theta_{1}$ 平面におけるマニピュレータの姿 勢を求める。以下に，同図中に付した※印の部分につ いて補足説明を行う。

マニピュレータが $G$ まで直線的に向かう途中， $\theta_{1}$ 平面に抢ける補間姿勢 $\Theta_{c_{i}}$ の状態でそのリンクが $\boldsymbol{B}_{i}$ と干涉する場合（すなわち， $\boldsymbol{B}_{i}$ を構成する辺群とマ ニピュレータの各リンクの辺群が交点をもつ場合), そこから離脱できる姿勢を求める必要がある。この干 涉状態と，離脱状態すなわちマニピュレータにとって の自由空間との境界は, リンクが障害物と接触する状 態である。

さて, 二次元平面内の 2 多角形間の幾何学的な接触 は, 一方の各頂点と他方の各辺との間で生ずる(10)。 そこで, $\boldsymbol{B}_{i}$ を構成する頂点 $\boldsymbol{B}_{i j}(j: 1$ からら多角形 の頂点の数まで）の各点および点間を結んだ線分と， $\theta_{1}=\theta_{1}$ の状態にあるマニピュレータのリンクを $\theta_{1}$ 平 面上に投影した各辺および各頂点との間で接触状態を 調べる。

電学論D, 111 巻 6 号, 平成 3 年

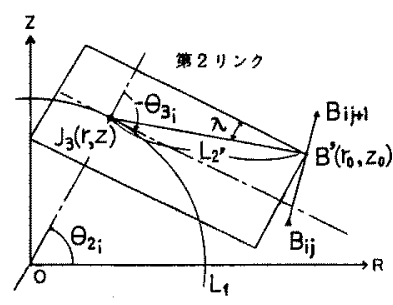

図 7 第二リンクのかどと障害物の 1 辺の接触 Fig. 7. Contact of 2nd link corner with an edge of an obstacle.

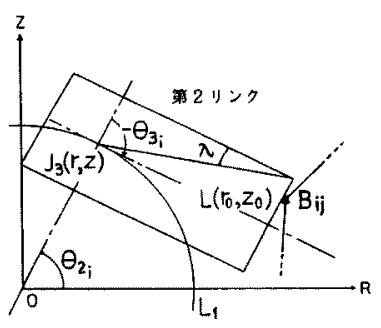

図 8 第ニリンクの 1 辺と障害物の頂点の接触 Fig. 8. Contact of 2nd link edge with a vertex of an obstacle.

本研究の寒験では，第 4 章で述べるように，障害物 が第ニリンク部位と干涉をきたすように設置される。 第二リンクと $\boldsymbol{B}_{i}$ が接する状態を図 7 および図 8 に表 す。図 7 では，第二リンク先端の角と多角形に近似さ れた障害物の1辺が接触した状況を示しており，障害 物辺上の 1 点 $B^{\prime}\left(r_{0}, z_{0}\right)$ 定めれ代，長さ $L_{2}^{\prime} た ゙ け \theta_{3}$ 軸方向へ戻った $J_{3}(r, z)$ を算出することができ，これ より $\Theta_{i}=\left(\theta_{2,}, \theta_{3_{i}}\right)$ は同図中の記号 $\lambda$ などを用いて，

$$
\begin{aligned}
& \theta_{2_{i}}=\tan ^{-1} \frac{z}{r} \ldots \ldots \ldots \ldots \ldots \ldots \ldots \\
& \theta_{3_{i}}=-\lambda-\tan ^{-1} \frac{z_{0}-z}{r_{0}-r}-\theta_{2_{i}}
\end{aligned}
$$

と求めることができる。

また，図 8 は第二リンクの1辺と障害物の 1 媔点が 接触している状態を示しており，この場合も同様にし てリンク辺上の 1 点 $L\left(r_{0}, z_{0}\right)$ を定めることにより, (2)，(3)式によって $\Theta_{i}$ を計算することができる。 $\theta_{1}$ 平面内で第二リンクが障害物と接するような姿 勢は無数に存在するので, 次に， $\Theta_{c i}$ の状態から最小 時間でリンクが障害物から離脱するという条件を導入 する。本マニピュレータは， $\theta_{2} お よ ひ ゙ \theta_{3}$ の最大角速

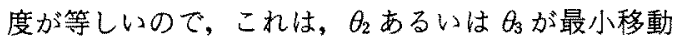
量で離脱できるマニピュレータの姿勢を求めることを 意味する。そこで，まず図 7 の $\boldsymbol{B}_{i}$ の辺に㳂って点 $B^{\prime}$ 


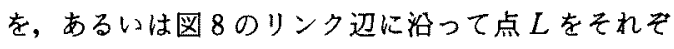
れ離散的に変化させながら，そのつど(2)，(3)式に よって $\Theta_{i k}\left(k: \theta_{1 s}\right.$ 平面内で離散的に変化させた点 $L$ あるいは点 $B^{\prime}$ の数)を算出する。そしてその中から，

$$
\begin{aligned}
& \Delta \theta_{k}=\max \left(\left|\theta_{3 c t}-\theta_{3 k k}\right|,\left|\theta_{2 c t}-\theta_{2 i k}\right|\right) \\
& \Delta \Theta_{i}=\min _{k} \Delta \theta_{k}
\end{aligned}
$$

の条件を満たす $\Theta_{i l}\left(l: \theta_{1}\right.$ 平面内の候補の数 $)$ をす べて求める。

そして，(5)式で求めた各 $\theta_{14}$ 平面内の候補 $\Theta_{i}$ の うち、いずれかの姿勢を各 $\theta_{1 i}$ 平面内でとりながら $S$ から $G$ まで移動させるときに,

$$
\min _{l}\left(\sum_{i=S}^{G} \Delta \Theta_{i l}\right)
$$

を満たす経路を後戻り探索によって求め，これを最終 的な大域的計画経路の出力とする。

〈3.2〉局所的な経路变更 前節で述べた大域的 な経路の計画は，以下に揭げる三つの点で不十分で ある。

（1）実際のマニピュレータには横幅方向にも肉厚 があるので，準空間 $\theta_{1}$ 内のマニピュレータの姿勢の 計算では，これを考慮しなくてはならない。これにつ いては， $\theta_{1}$ の変化につれてリンクの形状を準空間で ある平面に投影することによって逐一姿勢を計算する ことも可能である(11)。しかしながら, 計算量が增加 すること，また例えば，マニピュレータのリンクが円 柱形状であるような場合には，投影像が時々刻々に変 化するため，取扱いが煩雑になるなどの問題がある。

（2）準空間を決定するパラメータ $\theta_{1}$ を䫽散的に 変化させるので, その離散值以外の值に対応する準空 間の記述や，その空間における経路の計画ができな い。これは, 準空間法に限らず第 1 章で述べた空間の 記述の方法すべてに共通する問題である。

（3）視覚センサのデータには検出誤差や死角が存 在するため, 経路の計画には修正や補正が必要であ る。これについては, 検出データから死角領域の幾何 学的状態を補間する手法も考案されている(12)が実時 間的な取扱いは困難である。

以上 (1)〜 (3)の問題を同時に解決する方策とし て、マニピュレータを実際に動かしているときに障害 物との干涉を監視し, 干涉が発生した場合に経路を変 更させる機能を考えることができる。そこで，視覚デ ー夕に近接覚一触覚センサからの干涉梌出データを加 味して, 動作経路を実時間的に変更する方法として以 下に示すプロセスを本システムに付加した。

〈3・1〉節で求めた大域的計画経路に沿ってマニピュ

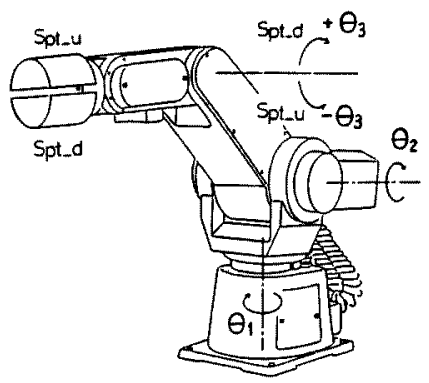

図 9 近接視覚信号に応じた第三ジョイント の動き方

Fig. 9. Driving rule of joit 3 according to proximity sensing signals.

レータが動作中に, 近接覚一触覚センサが取付けられ ている第二リンク部において障害物との衝突の可能性 を有する部位は, 上面もしくは下面, そして前面に の部分にはセンサが取付けられておらず，本研究では 回避の対象としない)である。障害物の位置およびこ れと干涉するリンクの部位は, 経路計画の段階であら かじめ求められているので，近接覚センサが働いた場 合には，その $\theta_{1}$ 平面内でそれぞれの部位を障害物か ら遠ざけるように $\Theta_{i}$ を変更させるのが適当である。 その速度ベクトル量は, 例兄ば図 7 では,

$$
\left(\Delta \theta_{2}, \Delta \theta_{3}\right)^{T}=J^{-1}(\Delta r, \Delta z)^{T}
$$

として与えることができる。ただし $(\Delta r, \Delta z)$ は，

$$
\left.\begin{array}{l}
\frac{\Delta z}{\Delta r} m_{j}=-1 \\
\Delta r^{2}+\Delta z^{2}=d^{2}
\end{array}\right\}
$$

を満たす量であるとする。また，（7）式の $J$ は，リ ンク先端の位置 $(r, z)$ について,

$$
J=\left[\begin{array}{ll}
\frac{\partial r}{\partial \theta_{2}} & \frac{\partial r}{\partial \theta_{3}} \\
\frac{\partial z}{\partial \theta_{2}} & \frac{\partial z}{\partial \theta_{3}}
\end{array}\right]
$$

で求められる $2 \times 2$ のマニピュレータヤコピ行列, 更 に, $m_{j}$ 注線分 $\boldsymbol{B}_{i j} \boldsymbol{B}_{i j+1}$ の傾き, $d$ は単位時間の経路 変更移動量であるとする。

しかし本システムでは，近接覚信号が $\theta_{3}$ 軸のサー ボ系にだけフィードバックされているので, 図 9 に示 すように，下面の近接覚センサ $S_{p_{-\alpha} d}$ の検出信号によ つて $\theta_{3}$ を正転方向に,また,上面のセンサ $\boldsymbol{S}_{\boldsymbol{p t . u}}$ では $\theta_{3}$ を逆転方向に回転させるようにし，その回転速度 量は, 図 3 の特性に従ったものを与えることにした。 一方, 触覚センサが働いた場合には, 高速な直接サ 一ボによる回避動作だけでは障害物を回避しきれなか 


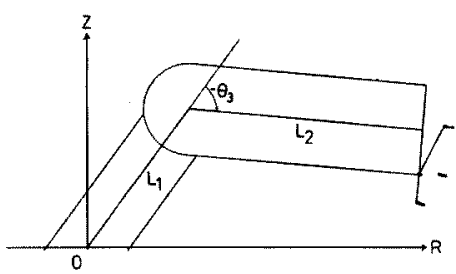

図 $10 \theta_{1}=-2^{\circ}$ における第二リンクと 障害物との接触

Fig. 10. Contact of 2 link with the obstacle when $\theta_{1}=-2^{\circ}$

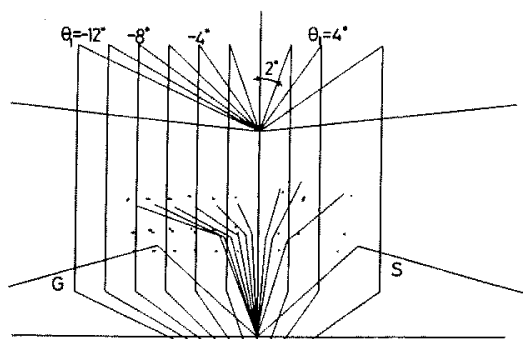

図 11 階段状障害物を回避する動作経路の 計画結果

Fig. 11. Result of path planning to avoid a stair-shaped obstacle.

ったとして，割込み信号によってマニピュレータの動 作を停止させて，再び経路ナ゙ラナに制御権を渡す。

\section{4. 障害物回避動作の結果と考察}

図 3 に表した階段状の物体を障害物とみなし，第 3 章で提案した制御手法によって，マニピュレー夕にこ れを回避させる動作を実現した。

まず，準空間においてマニピュレータが動作し得る 姿勢を求めた例として，図 $10 に 一 2^{\circ}$ 平面におけるマ ニピュレータの障害物との接触の様子を示す。図中の 右側の黑点は障害物の検出点を表している。障害物の 凸多角形近似によって障害物の点が削減され，これら を結んだ線上の一点とマニピュレータ第二リンクの前 下かどが接触している状態を表している。また図 11 は，マニピュレータが障害物を回避しながら $S$ から $G$ へ向かう姿勢の変化を

$$
-12^{\circ} \leqq \theta_{1} \leqq+6^{\circ}
$$

の範囲において $2^{\circ}$ 間隔でリンク線表示したものであ る。同図加ら，それぞれの $\theta_{1}$ 平面内でマニピュレー タが障害物を回避する姿勢が計画されていることがわ かる。

経路プラナとしてワークステーションNWS-811

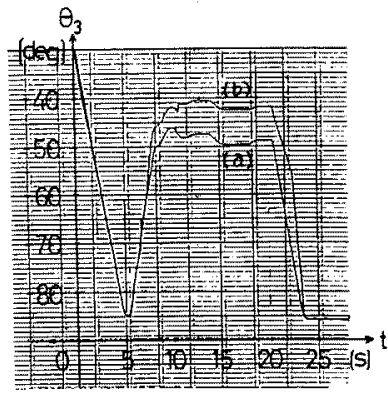

(a)障害物を除き，計画経路に往った場台

（b）障害物を圈き，近接覚による経路变更を伴った場合

図 12 第三ジョイント角度のモニタ

Fig. 12. Monitor of joint 3 angle.

（2.3 MIPS）を用いた。計算処理時間は，各 $\theta_{1}$ 平面 内の姿勢決定(図 10)に約 $0.3 \mathrm{~s}$ ，また，全 $\theta_{1}$ 平面の 障害物点 118 点に対して大域的な計画経路を探索する のに(図 11) $3.3 \mathrm{~s}$ を要した。更に，(10)式に表す範囲 において $\theta_{1}$ パラメータの間隔を $4^{\circ}$ とした場合でも回 避動作は実現でき，そのときの全経路の探索所要時間 は $1.6 \mathrm{~s}$ に短縮された。

図 12 は近接覚一触賞センサを働かせながら実際にマ ニピュレータを制御したときのジョイント角 $\theta_{3}$ の変 化を回避動作の $18 \mathrm{~s}$ の間, 第三ジョイントに取付け たポテンシオメータによってモニタしたものである。 同図には，特にマニピュレータが障害物に接近する時 点あるいは障害物から觪れる時点において, 近接覚信 号に従って局所的にオーバランしている様子が示され ている。この実験では，準空間の中で経路を計画する 段階で，姿勢探索アルゴリズムの中に時々刻々変化す る肉厚部の計算処理など煩雑なルーチンは加えられて いない。にもかかわらず，実際にマニピュレータが動 作するときに近接覚センサデータを統合して $\left(\Delta \theta_{3}=\right.$ $7^{\circ}$ 程度の) 経路変更を行うことにより, 計算処理時 間を短縮することができ，また確実に障害物回避動作 が実現できることが実験結果からわかる。

\section{5. 結言}

本論文では，2リンクマニピュレータによる自律的 かつ赛時間的な障害物回避動作を目的として, 視覚七 ンサおよよび近接覚一触覚センサを実装したシステムの 構成について述べここれらのセンサから得られたデー 夕を統合的に利用する制御戦略を提案した。そして, 動作実験を通じてシステムの応答時間に関する評価を 行った。本論文で得られた成果を以下の 3 点に要約 する。 
（1）マニピュレータの視覚として, 三次元位置検 出センサを装着し, また, 実時間的な干渉チェックを 目的として近接覚一触覚センサを第ニリンク部に装着 したセンサ統合システムを構築した。

（2）視覚情報を用いて経路プラナで大域的な動作 経路を計画するプロセスと, 近接覚・触覚情報をジョ イントサーボ系に直接フィードバックして局所的に経 路を変更するプロセスを組合せた制御戦略を提案し た。

（3）本マニピュレータシステムが階段状の障害物 を実際に回避する動作の所要時間は全体でおよそ $22 \mathrm{~s}$ で，そのうち経路計画に要する時間は $3.3 \mathrm{~s} に$ 短縮さ れた。これにより, 構築したシステムの応答の高速化 およびその有効性が確認された。

本制御戦略においては, 局所的な経路の変更を $\theta_{1}$ 平面内でヒューリスティックに行っている。この動作 の収束性については, 既に考察が与えられてい る(13)。しかしながら， $\theta_{1}$ 平面から外れて経路を変更 しなければならないような場合には, 更に力覚センサ などを利用して障害物との接触時に回避の方向ベクト ルを定めるアプローチ(14) などが有効であると考えら れる。

最後に, 本論文にまとめるにあたり, 御助言をいた だきました東京工業大学教授梅谷陽二先生に深く感 謝いします。また, システムの構築にあたり，プログ ラム開発に御助力いただきました松下昌之君（現, 住 友ゴム)ほかに感謝いたします。なお，本研究の一部 は, 昭和 63 年度科学研究費補助金(課題番号 63750428）によって達成されました。

(平成 2 年 4 月 2 日受付, 同 2 年 9 月 27 日再受付)

\section{文 献}

（1）小林：「自律形移動ロポットにおける知識処理」, 計測と制 御, 26, 128 (昭 62-2)

(2) G. Giralt, R. Chatila \& M. Vaisset: "An Integrated Navigation and Motion Control System for Autonomous Multisensory Mobile Robots", Proc. 1st Int. Symp. Robotics Research, p. 191 (1983)

（3）久保田・欈本・原島：「視覚センサとレンジセンサの協調に よる移動ロポットのナビゲーション」, ロボット学誌, 7.11 (平元-4)

(4) O. Khatib: "Real-Time Obstacle Avoidance for Manipula. tors and Mobile Robots". Int. J. Robotics Res.. 5. 90 (1986)
（5）長谷川:「口ポットひ作業環境記述上動作計画に関寸る研 究」, 電総研報告, No. 894 (昭 63)

(6) T. Lozano-Pérez: "Spatial Planning: A Configuration Space Approach", IEEE Trans. Computers, C-32, No.2, 108(1983)

(7) Y. Yamada, N. Tsuchida \& M. Komai: "Visual and Proximity.Tactile Sensors for Collision Avoidance Control of an Industrial Manipulator", Proc. 19th ISIR, p. 741 (1988)

（8）山田・土田・駒井・平川：「微分処理により抽出された特徵 点の 3 次元位置を検出するレーザ光走查型センサ」, ロボッ 卜学誌, 7,23 (平元-6)

（9）山田・土田・上田：「同筒形アームのための障害物検出用近 接賞一触覚センサ」, 同上, 6, 292 (昭 63-4)

(10) T. Lozano-Perez: "Motion Planning for Simple Robot Manipulators", Robotics Res., 3, 133(1985)

(11) A. Rodney: "Planning Collision-Free Motions for Pickand-Place Operations", Int. J. Robotics Res., 2, No. 419 (1983)

（12）広瀬・前川・梅谷：「地図作成型視覚システムの情報処理」, ロボット学誌, 2, 191 (昭 59-3)

(13) V. J. Lumelsky: "Dynamic Path Planning for a Planar Articulated Robot Arm Moving Amidst Unknown Obstacles", Automatica, 23, 551(1987)

(14) K. Kosuge, K. Furuta \& T. Tokoyama: "A Control Architecture for Intelligent Mechanical System: Visual Internal Model Following Control". Proc. IEEE Int. Symp. Inteligent Control, p. 489(1987)

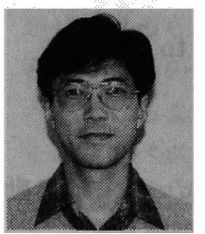

山田陽滋 (正員)

昭和 56 年 The University of Texasに留学, M. S. 取得。 58 年 名古屋大学工学部修士課程修了。同 年豊田工業大学制御情報工学科汇勤 務。工学博士。以来, ロボットのセンサおよび制御の 研究に従事。平成元年電子情報通信学会東海支部創立 50 周年記念将励賞受賞。

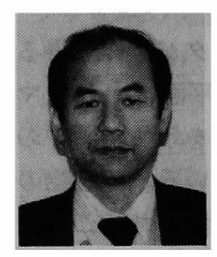

\section{土田縫夫（正員)}

昭和 47 年名古屋大学大学院博士 課程満了。名古屋大学助手を経て, 現在, 豊田工業大学制御情報工学科 助教授。工学博士。主として, 薄膜 トンネルエミッタ素子を応用した液体誘電体物性の研 究, ロボット用アクチュエータおよびセンサの研究に 従事。 46 年電気学会論文賞受賞。 